\title{
腰椎椎間板外側ヘルニアの診断と治療
}

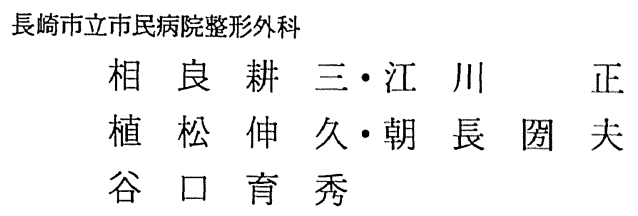

\section{Diagnosis and Surgical Treatment of Extreme Lateral Lumbar Disc herniation}

by

\author{
Kozo Sagara, Tadashị Egawa, Nobuhisa Uematsu, \\ Kunio Tomonaga and Yasuhide Taniguchi \\ Department of Orthopaedic Surgery, Nagasaki \\ Municipal Hospital, Nagasaki, Japan
}

\begin{abstract}
Extreme lumbar disc herniation (ELLDH) is one of the diagnotic difficulties of nerve root impingement in the hidden zone. We have surgically treated thirteen patients with ELLDH, and report on their diagnosis and the surgical approach used.

Subjects comprised 13 patients, (11 male, 2 female) ranging in age at surgery from 25 to 68 years (mean 46.3 years). The locations of disc hernia were intraforaminal (IF, 7 cases), and extraforaminal (EF, 6 cases).

Myelography was of no value in the diagnosis of $\mathrm{EF}$ but implied the level of the herniated disc in IF. Discography and radiculography were more valuable for diagnotic establishment of IF. Cross sections of CTM and MRI supplied very important findings of EF. Regarding surgical procedure, the cases of IF were treated by unroofing (six cases) and hemilaminectomy (one cases), three cases of $\mathrm{EF}$ have been recently treated by osteoplastic hemilaminectomy without fusion instead of facet destructive procedure which was used earlier.

Accuracy of preoperactive diagnosis and appropriate selection of surgical approach are needed for ELLDH.
\end{abstract}

Key words : extreme lateral lumbar herniation (腰椎椎間板外側ヘルニア), intraforaminal type (椎 間孔内型), extraforaminal type（椎間孔外型）

$$
\text { はじめに }
$$

腰椎椎間板外側ヘルニアの intraforaminal type と extraforaminal type とでは診断と治療に若千の相違 があるが2，この点を詳細に述べた報告は少ない，今 回, 本症の自験例に対して両タイプの診断と治療上の 留意点を検討したので報告する。

\section{対象および方法}

症例は 1986 年以降当院にて本症の診断のもとに手 術を行った男性 11 例, 女性 2 例の計 13 例であり, 手 術時年齢は 25 歳から 68 歳, 平均 46.3 歳であった。 経過観察期間は 6 力月加 8 年 4 力月, 平均 2 年 11 カ月であった。ヘルニア高位は L2/3 1 例, L3/4 3 例, L4/5 4 例, L5/S1 5 例であった. ヘルニアの位 
置は intraforaminal type（以下 IF と略す） 7 例， extraforaminal type（以下 EF）6例であった．本 症の診断に関して, 臨床症状及び神経学的所見の特徴, 画像的検査の有用性を検討した，治療に関しては，診 断に基づく手術方法の選択と推移を述べ，術後成績を JOA スコアにより評価した。

\section{結果}

1. 臨床症状および神経学的所見：臨床症状として 腰痛 11 例（84.6\%)，下肢痛 13 例（100\%）に認めた。 特に下肢痛は激烈で，歩行困難あるいは不能を伴うも のであった，神経学的所見では，SLRT 陽性 10 例， FNST 陽性 3 例で, 全例どちらかのテストが陽性で あった，神経悦落症状を 9 例 (69.2\%) に認め，筋力， 知覚低下は各々 6 例 (46.2\%)，7例（53.8\%）にみら れた.

2. 画像検查所見 : 各程画像検查の異常所見の有 無を表に示したＩFでは全体的に検祖数が少なかっ た. 同 type では myelography と CTM で異常所見 が多かったが碓定診断に至ったものはCTM の1例の みであった．椎間板造影や神経根造影により診断が碓 定したものが 4 例で，他の 2 例は手術峙に非明した。 矢状断の MRI で 2 例に椎間板レベルより下方転位し たヘルニアを認めた．EF では myelography で所見 を認めたものはわずかであり，診断価值はほとんどな かったが，CTM または MRI の横断像により全例確
定診断が可能であった．他の補助診断でさらに明白と なった（表1).

3.ヘルニアの形態と神経根障害部位: 手術時確認 したヘルニアの形態を国際会議分類により protrusion, extrusion, sequstration に分類した. protrusion はなく, extrusion 7 例 (IF 3 例, EF 4 例), sequestration 6 例（IF 4 例, EF 2 例) であった. IF は sequestration が多く, EF は extrusion が多かっ た. IF 7 例中 6 例は下方転位があり， 1 例は上方転 位があった。神経根障害は IF の上方転位の 1 例と $\mathrm{EF}$ の全例が榷患椎間より 1 つ上方のレベルであっ た.

4. 手術方法および術後成績: 手術方法は IF の 6 例に unroofing, 1 例に hemilaminectomy を行い, そのうち 1 例に後側方固定を追加した．EF では椎間 関節切除術, hemilaminectomy, 外倒開空術各 1 例 行い，前者 2 例には後側方固定を追加した．最近の 3 例は骨形成的偏側椎弓切除術を行い，固定は併用しな かった. JOA スコアは術前 2 点〜12 点, 平均 7.0 点 であったが, 術後 19 点〜29 点, 平均 23.9 点であり, 平均改善率 $75.9 \%$ と全例改善を認め, 再発例はなかっ た.

\section{症 例 供 覧}

症例 1.34 歳男性. 左下肢痛を主訴に, 近医通院 治療 2 カ月後に来院した. myelography, CTM では

表 1，画像㭘査の罢常听見の有然

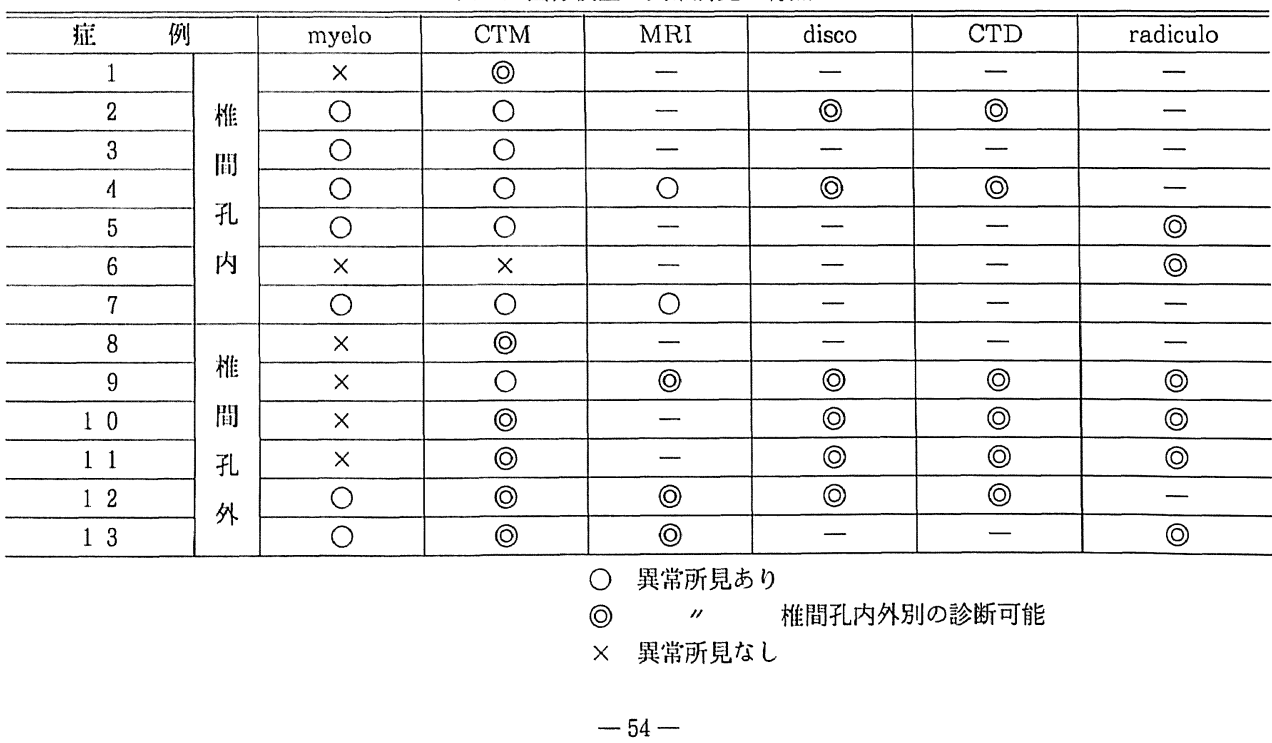


左S1 root の欠損を認めたが，明らかな外側へルニ アの所見はなかった．神経根造影では左 S1 pedicle 付近で途絶を示した. MRI 矢状断では L5/S1 椎間板 より下降したへルニアを認めた。手術は unroofing により展開したが, subpedicular zoneにヘルニア塊 が migrationしていた (図1a-f).

症例 2.40 歳男性. 腰痛及び左下肢の激痛により 至急入院となった。ミミロと同時に行った神経根造影
では L5/S1 椎間板外側では途絶を認めた。CTM， discography, CTD とも明らかに extraforaminal hernia の所見を認め, 手術は骨形成的偏側椎弓切除 術によりへルニアを摘出した（図2 $\mathrm{a}-\mathrm{f}$ ).

症例 3. 初診の 2 年半前に他病院にて 2 度の L $4 / 5$ のヘルニア摘出術を受けていたが，右下肢䚫が再発し た. CTM, MRI および CTD で L4/5 の大きな extraforaminal hernia が明らかとなった。手術は痽

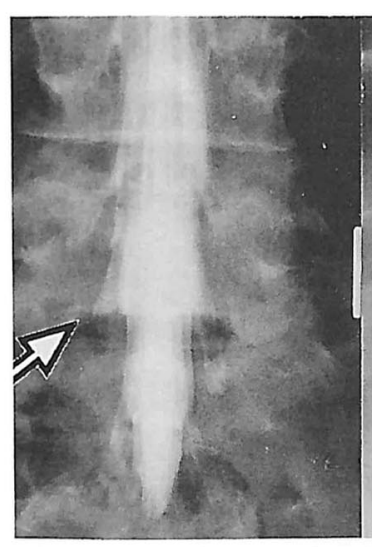

a.

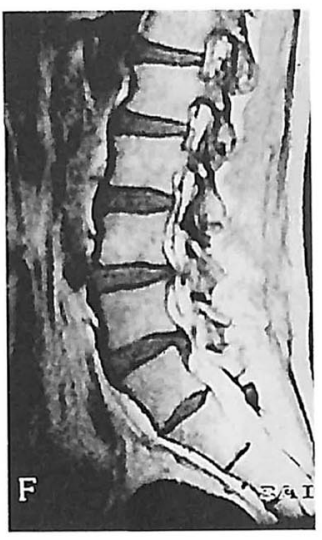

e.

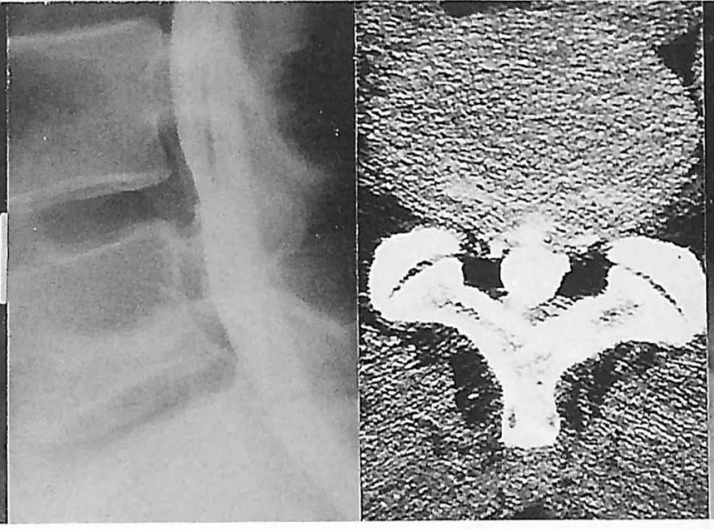

c.

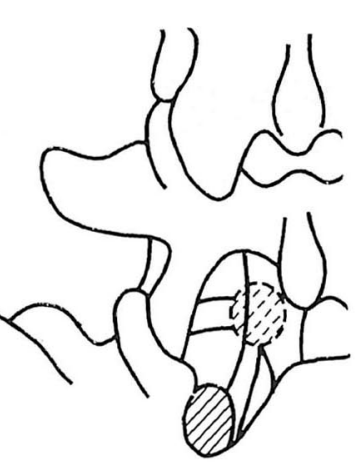

f.

図1。症例 1。34 歳 男性.

a, b. myelography 左 Sl root の欠損を認める.

c. CTM でもSl rootの欠損を認めるが, 外側ヘルニアの所見はみられない.

d. 神経根造影 左 Sl pedicle 付近で途絶している.

e. MRI L5/S1 椎間板で下降したヘルニアを認める.

f. 手術時所見 unroofingによるアプローチ. 左S1の sub pedicular zone ヘのヘルニア塊の migration を認めた. 
着が強いため，椎間関節切除を含む hemilaminectomy を行い, 巨大なヘルニア塊を摘出し, 後側 方固定を追加した（図 $3 a-f)$.

\section{考察}

腰椎椎間板外側ヘルニアの診断は MRI の出現や症 例報告増大による検者の認識向上により必ずしも困難 でなくなったが，発症頻度が低く，見落とす恐れがあ る. 臨床上著明な下肢痛による歩行困難があるにもか かわらず, myelography の所見がそしかったり，神
経学的所見が慛患椎間レベルと異なる場合は本疾患を 念頭に入れる必要があると考えられる(13)5).

画像検査ではIF の場合 myelography で異常所見 を認めることが多く，䍜患椎間を示唆するむのであっ たが，外側へルニアを診断するまでには至らず，やは り椎間板造影や神経根造影に診断価值が高かった。 CTM, MRI の横断像は intraforaminal space が小さ いため，たとえ所見があっても確定診断には不安を感 じた.しかし，矢状断像の MRI 像では椎間板レベル より上下方向に偏位したへルニアを認めることがあり，

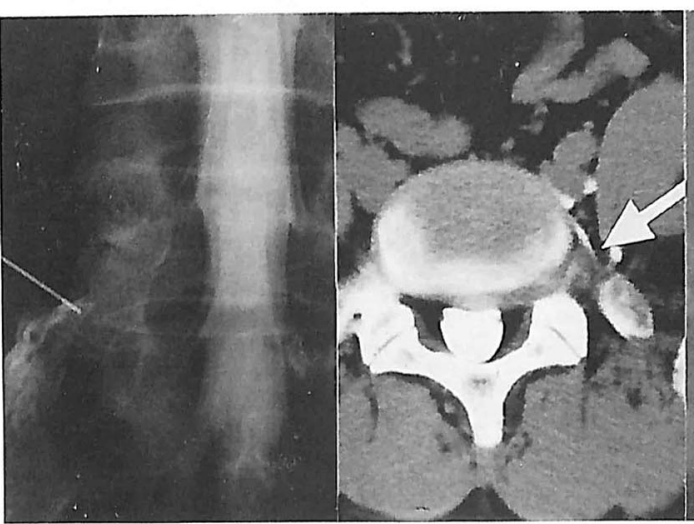

a.

b.

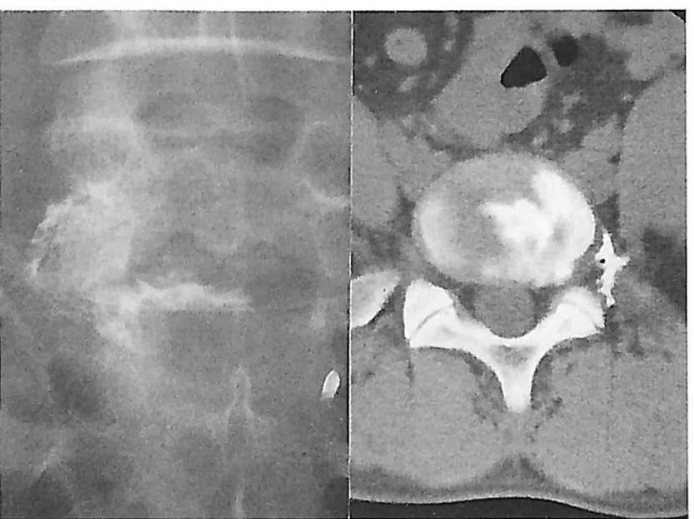

c.

d.

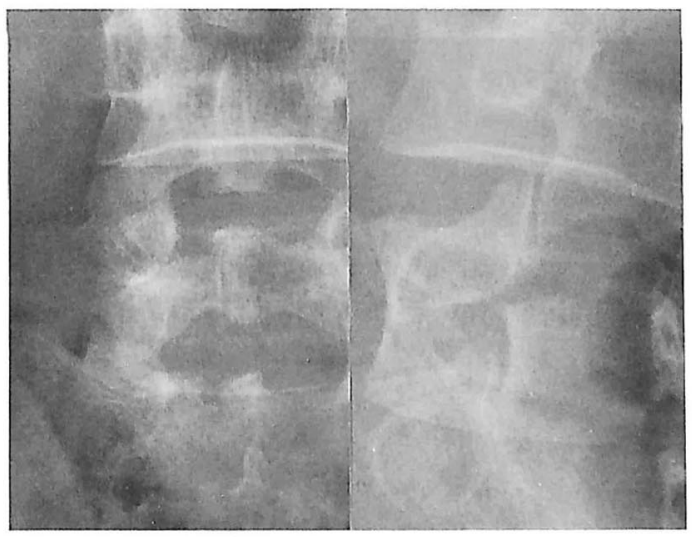

e.

f.

图 2.40荿 男性.

a. myelographyと同時に行った神経根造影 左 L5 root は L5/S1 椎間板外侧で造影の途絶が みられる。

b. CTM c. 椎間板造影 d. CTD

b. 一d. とも extraforaminal hernia の像を示す。

e, f . 骨形成的椎弓切除術後の X - P. 
手術時の検索に有意義であると考えられる。これに反 してEF の CTM やM R I の横断像は診断に非常に有 用であった ${ }^{13)}$. 当院では CTM, MRIは 1 椎間板あ たり 3 カ所の横断を routine に撮っており，これも診 断率の高かった理由と考えられる(図 4).

手術方法は IF では羅患椎間よりヘルニアの上方転 位の場合 hemilaminectomyを，下方転位の場合 unroofing を行っている. 椎間関節が温存されれば基 本的には固定は必要ないと考える，EFの手術では初 期には椎間関節部の破壊が強い手術法であったため固
定術を併用した，最近では骨形成的椎弓切除術を固定 の併用なしに行い，短期的ながら良好な結果を得た (図 5 ). 同法は外側開空術などに比べ術野も広く, 切 除椎弓の還納により術後の不安定もさほよ゙心配ないよ うであるが4，今後の経過を十分観察したい。

$$
\text { ま と め }
$$

1. 腰椎椎間板外側ヘルニア手術例 13 例の診断及 び治療の留意点について喻討した。

2. IF は7 例で, うち 6 例は下方転位, 1 例は上

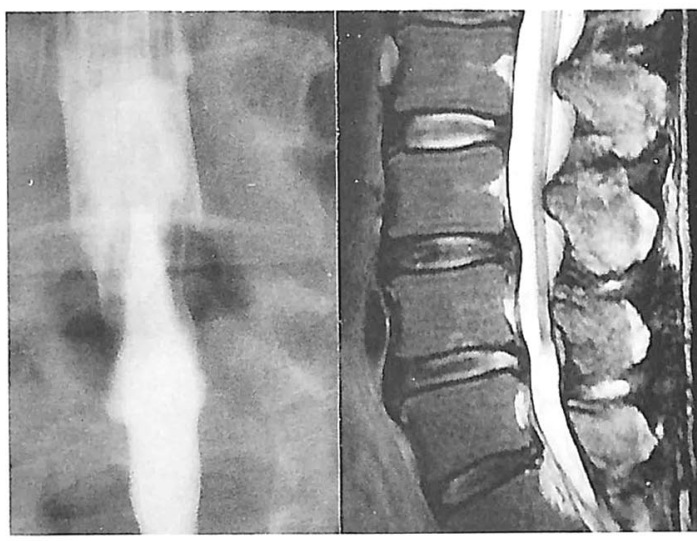

a.

b.

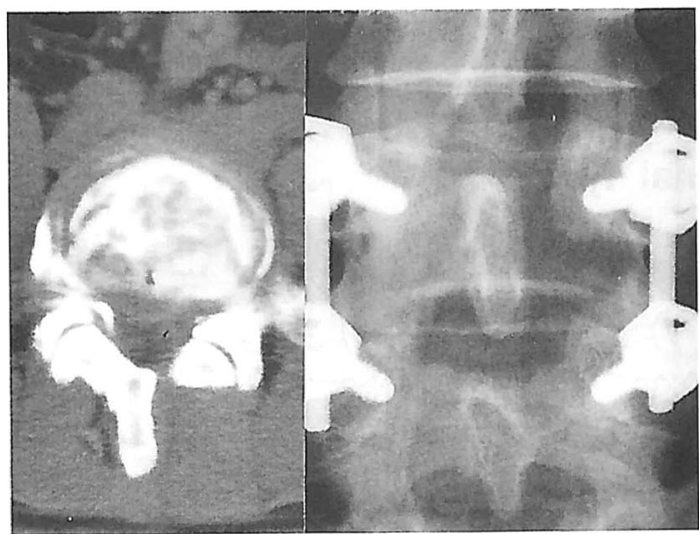

e.

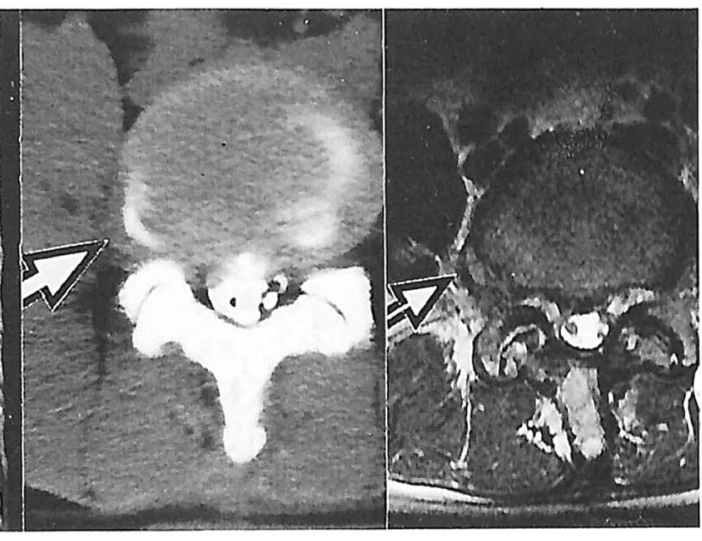

d.

図3.37 歳 男性.

a. myelography，前回手術による緳痕狭窄所見あり.

b. MRI (矢状断)。 L3/4, L4/5 の椎間板の buldging を認める.

c. CTM. d. MRI (横断). e. CTD.

c. 一 e.上も extraforaminal hernia の像を示す.

f . 椎間関節切除を含む hemilaminectomy + PLF 術後のX-P. 

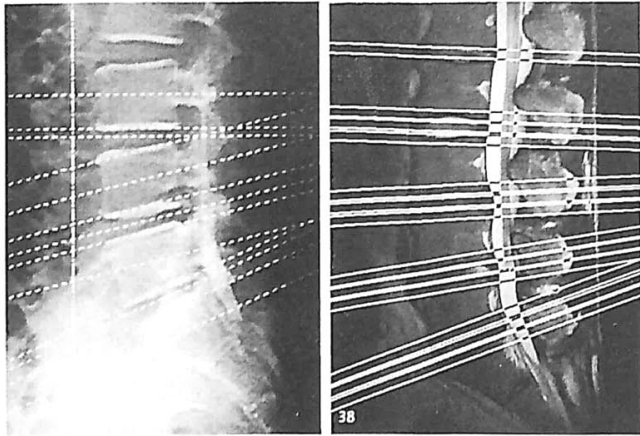

図 4. CTM と MRI の横断像検查 1 椎間板あたり 3 筒所の断層を routine に行っている.

\section{intraforaminal type}

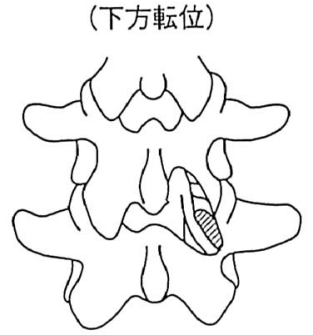

unroofing

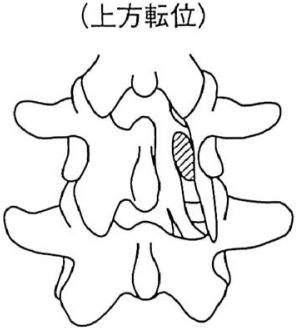

hemilaminectomy

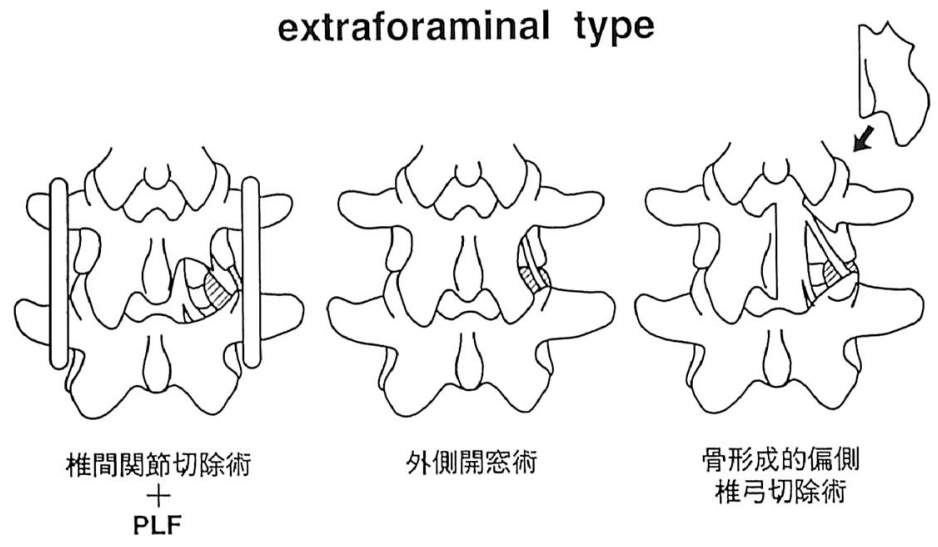

図 5、腰椎椎間板外側ヘルニアの手術治療 
方転位であったＥF は6例であったＩF の確定診断 には椎間板造影や神経根造影が有用であることが多く, 手術時判明したあのも2 例あった. EF はCTM, MRI による確定診断が全例可能であった.

3 . 手術方法は IF で unroofing と hemilaminectomy で対処した. EF の最近の 3 例は骨形成的片側 椎弓切除術を行い，短期的に良好な経過を得た。

\section{参考文 献}

1）岩村祐一，ほか：椎間孔内・外腰椎椎間板へルニアに
対する術式の検討. 整形外科, $45: 1358-1364,1994$.

2) Macnab I. : Negative Disc Exploration. J Bone Joint Surg., 53A : 891-903, 1971.

3）戸口 淳, ほか：外側型腰椎椎間板ヘルニア（椎間孔 内・外）の 7 手術例. 整形外科, $45: 567-572,1994$.

4）豊田耕一郎，ほか：腰椎椎間孔外倒へルニアに対する 骨形成的偏側椎弓切除術. 春椎脊随, 7:597-601, 1994.

5）植松伸久，ほか：Lateral Lumbar Disc Herniation の 7 症例. 西日本脊椎研究会誌, $18: 114-117,1992$. 